\title{
Anthropogenic Transformation of Landscapes of Colchis Lowland and Surrounding Foothills
}

\author{
Dali Nikolaishvili $^{1}$, Elene Salukvadze ${ }^{2}$, Nana Bolashvili ${ }^{2}$, Nino George Chikhradze ${ }^{2}$, \\ Lia Matchavariani ${ }^{1}$ \\ ${ }^{1}$ Department of Geography, Ivane Javakhishvili Tbilisi State University, Tbilisi, Georgia \\ ${ }^{2}$ Vakhushti Bagrationi Institute of Geography, Ivane Javakhishvili Tbilisi State University, Tbilisi, Georgia
}

\section{Email address:}

dali.nikolaishvili@yahoo.com (D. Nikolaishvili), dali.nikolaishvili@tsu.ge (D. Nikolaishvili), elene.salukvadze@gmail.com (E. Salyukvadze), nana.bolashvili@gmail.com (N. Bolashvili),nchikhradze@yahoo.com (N. Chikhradze),likageotsu@hotmail.com (L. Matchavariani)

\section{To cite this article:}

Dali Nikolaishvili, Elene Salukvadze, Nana Bolashvili, Nino George Chikhradze, Lia Matchavariani. Anthropogenic Transformation of Landscapes of Colchis Lowland and Surrounding Foothills. Earth Sciences. Special Issue: Modern Problems of Geography and Anthropology. Vol. 4, No. 5-1, 2015, pp. 68-72. doi: 10.11648/j.earth.s.2015040501.22

\begin{abstract}
On the basis of different data, the anthropogenic transformation of landscapes of Colchis lowland and surrounding foothills (CLSF) are revealed. Using the several maps (Vegetation and Landscape maps, topographic maps, depicting the different historical periods), the degree of these changes were determined. Data analysis has shown that the anthropogenic transformation of Colchis landscapes is of very diverse character and this diversity is related to many physical-geographical and human factors.
\end{abstract}

Keywords: Landscape, Anthropogenic Transformation, Colchis Lowland and Foothills

\section{Introduction}

Determination of anthropogenic transformation of landscapes is one of the main objectives of geographical research in recent years, as it is of great constructive importance in addition to the scientific-theoretical one, It is important to determine the anthropogenic transformation scale to identify a natural-resource potential, contemporary conditions, current trends in landscapes, territorial planning and management.

There are a lot of data, amassed in different branch-geographical literature and scientific-research organizations, which pose difficulties in their comparison and study the issue toward the landscapes. In this regard, data classification and systematization is very important. Study of anthropogenic transformation of some territory on the basis of landscape approach is quite appropriate and representative in solving the problem.

Aim of the present research is the evaluation of anthropogenic transformation of Colchis lowland and surrounding foothills and determines the current trends in the landscapes.

Colchis lowland and surrounding foothills (CLSF) is a region of high natural-resource potential. On the other hand, it is significantly transformed because of the impact of economic activity. Topographical peculiarities (existence lowland and foothills) determine the diversity of landscapes in approximately small area. Interest to it is even greater, if we take into account the fact that there are the untouched landscapes stretched over the significant areas beyond the transformed territories. Many species of the Tertiary flora are survived here - in Colchis refugium. It is characterized by a high level of flora and fauna endemism.

\section{Research Methods and Initial Data}

In line with the research objectives, a variety of factors were analyzed. For determination of the degree of anthropogenic transformations of CLSF, lot of following cartographic sources was used:

- Map of Existing Restored Vegetation [1]; it represents the distribution of the vegetation cover in the past, before the anthropogenic factor became stronger (scale 1:600,000);

- Landscape Map of Georgia [2]; it represents the Natural-Territorial Complexes (NTCs) in 1980s (scale 
1:500,000);

- Topographic Maps of Georgia (of 1:200,000 and 1:100,000 scale);

- Google Earth Maps.

Phytomass average quantities ( $\mathrm{t} / \mathrm{ha}$ ) and the stock $(\mathrm{t})$ was identified on the basis of data existing in the scientific literature [3-5].

The demographic impact assessment on landscapes was based on the data of 1989 and 2002 census.

The anthropogenic transformation of landscapes of CLSF were determined due to different parameters, such as the change of forest area, the coefficient of demographic influence, phytomass amount, soil degradation, etc. This analysis revealed that landscape transformation is quite different according to several landscapes.

\section{Study Area}

CLSF is presented by the diverse range of landscapes, regardless of its small hypsometrical range and that its entire territory is located in the subtropical zone. Here can be found the coastal dunes with dry amateur psamophitic plants, alder and sedge-peat bogs, relic Colchis forests (mainly preserved in the Protected Areas), agricultural lands, and intensively fragmented dense drainage systems. Swampy areas are distinguished by rare and original flora and fauna. A number of endemic and relict species can be found here. In the local wetland landscapes it is worth to attention the existence of the tundra and taiga flora elements not familiar to subtropical latitudes, as well as the existence of species characteristic to high mountain areas and also the existence of the northern boreal elements. Scientists believe that a of glacial period relicts hit here as well, because it was an ancient flora refugium in the glaciations epoch [6-8]. Important natural resource is made by the abundance of medical herbs [9].

In CLSF's forest ecosystems, which are remained mainly in the Protected Areas, oak groves are common, which are made by the Georgian (Quercus iberica) and Colchis ( $Q$. hartwissiana) oaks, and in the wetlands areas - the alder (Alnus barbata) and wingnut (Pterocarya pterocarpa) groves [10].

Some of the swamped areas of CLSF are included in the Ramsar list of the Wetlands of International Importance, as it is a waterfowl habitat area. In addition, here runs one of the main bird migration ways from Africa to the temperate and polar zones of Eurasia and forms for local and migratory birds the resting or wintering place.

The 3 subtypes of landscapes are represented within the Colchis Lowland [11]:

1. Plain and Landscapes with Colchis forest (10 genera of landscapes). It is spread in western Georgia - in the Colchis Lowland and its foothill areas. Hypsometrically it is located at the height of 0-600 $\mathrm{m}$ above sea level and it is spread even up to $800 \mathrm{~m}$ above sea level in the eastern part of the Colchis Lowland (Imereti hillside). Its original natural look is much modified and farmlands stretch over the large areas. Untouched natural-territorial complexes are preserved only in reserves and Colchis wetland areas.

2 Plain and foothills sub-Mediterranean semi-humid, transitional to Colchis (2 genera of landscapes). It is spread over the small areas within the Bichvinta Cape and Kovaliuk hillside up to the height of $300 \mathrm{~m}$ above sea level. Because of the relatively little amount of the atmospheric precipitation during the vegetation period, the Sub-Mediterranean climate effect occurs, due to which there can be found the natural-territorial complexes which differ from the surrounding landscapes. Their original natural look has been better preserved.

3. Plain and lowland accumulative landscapes with wetlands of sphagnum and cane bog (2 genera of landscapes). It extends in the central part of the Colchis lowland and along the downstream of large rivers. Vegetation cover is of hydromorphic nature and the wetlands and riparian forests dominate there. One of the major peculiarities of these landscapes is the existence of a comparatively large amount of untouched areas.

\section{Main Results}

\subsection{Anthropogenic Development of the Territory}

Variation of environmental conditions for thousands of years caused the extinction of many species of caused change in landscapes, which was related to both, natural and anthropogenic factors. No region has experienced the anthropogenic change in Georgia, like Colchis Lowland. One of the significant changes was related to drainage of Colchis lowland wetlands. In particular, from 2.2 thousand $\mathrm{km}^{2}$ of wetland area in 1925-1936 were dried up to $58.2 \mathrm{~km}^{2}$ and in the years of 1936-1978 $-840 \mathrm{~km}^{2}$ of area, i.e. almost half of the Colchis wetlands have disappeared [12-14].

The fact that the Colchis Lowland was covered by a forest in the past is proven by a lot of evidences, such as fragments of forest, remains of buried forest, soil horizons typical to forest landscapes, toponyms, etc. According to different historical sources, Colchis, including its almost completely swamped western part, was covered by impassable forests. Old scholars - Strabo, Herodotus, Hippocrates and Xenophon declare the Colchis lowland as an area surrounded by the precious species [15]. Dominated forest and herbaceous wetlands characteristic to humid subtropical climate, as well as the lowland Colchis forest presented by variety of deciduous species.

Most of the Colchis plain landscape is transformed anthropologically by some extent. Their situation reflects not only the results of human action according to last decades, but it somehow "saved" the changes in itself that have been going on for a long time. Any modification of the landscape can be identified by: a) only natural processes, b) only anthropogenic processes and c) conditioned natural-anthropogenic processes. As believed, we deal with the last two processes of landscapes modification within the Colchis Lowland [16]. For example, accumulative lowland-plain landscape with hardly passable sedge wetlands vegetation, peat and peat-swamp soils and peat bogs has been replaced by a humid meadows landscape in 
the meadow clay soils. Thus, the swamp forming processes are changed by meadow forming processes and the meadow landscapes have been formed over a large area.

Vegetation cover of the region suffered a particularly strong anthropogenic impact. Exactly the anthropogenic transformation of vegetation cover especially that of forests can be considered the indicator of changes in natural conditions. There are stretched agricultural lands in many places instead of the previously existed impassable Colchis forest. And still preserved natural vegetation is significantly transformed because of the forest cutting, drainage and grazing. New vegetation communities have been formed, such as: secondary grassland and bushes, meadow vegetation and swampy meadow [17].

Trend of reduction of forest areas and forest cover is the result not only of the past, but it was pretty intense in the 2 nd part of the 20th century. All these changes have taken place in all landscapes (Fig. 1). It is interesting, that the same trend of forest area reduction is observed in almost all landscapes.

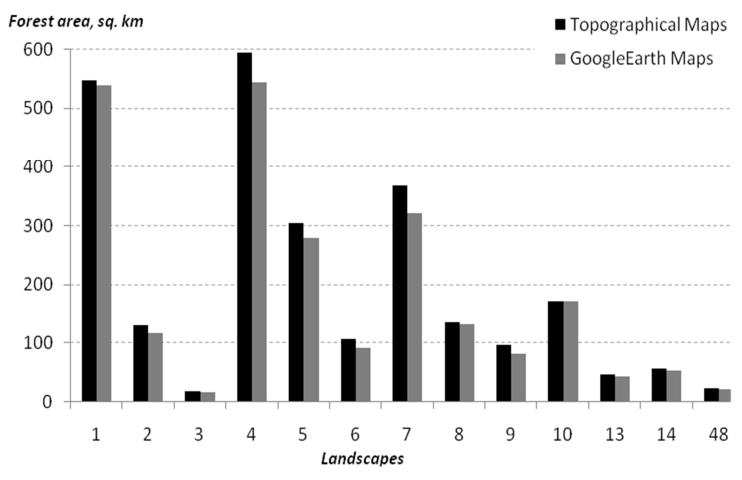

Figure 1. Change of Forest Area of landscapes of Colchis Lowland and Surrounding Foothills.

Landscapes Genera:

1. Lowland landscapes with swamp, alder forest and sphagnum bogs.

2. Lowland landscapes with oak forest, somewhere with evergreen understory.

3. Foothill landscapes with hornbeam-oak forest alternating with chestnut.

4. Foothills terrace denudation-accumulative landscapes with hornbeam-oak forest and polydominant forest in the gorges.

5. Foothill denudation-accumulative landscapes polydominant forest.

6. Lowland and foothill landscapes with hornbeam-oak, beech-chestnut, oak-zelkova and polydominant forest.

7. Foothill erosion-denudation landscapes with colchic hemihylaea.

8. Foothill karst landscapes with hornbeam-oak (Carpinus caucaisca, C. orientalis) polydominant forest with evergreen understory.

9. Foothill erosion-denudation landscapes with hornbeam-oak forest alternating with beech-chestnut, oak-zelkova and polydominant forest with evergreen understory.

10. Erosion-denudation plateau with landscapes with oak-beech-chestnut forest and evergreen understory.

13. Plain and lowland accumulative landscapes with Bichvinta pine.

14. Foothill erosion-denudation landscapes with hemixerophitic oak and polydominant forest and maquis.

48. Plain and lowland accumulative landscapes with wetlands (sphagnum and cane bog).

\subsection{Dynamics of Phythomass}

The highest amount of phytomass in Georgia is characteristic to middle-mountain forest dark-coniferous landscapes and it makes up $500 \mathrm{t} / \mathrm{ha}$ and higher. The second by the amount of phytomass is middle-mountain forest landscapes with the prevalence of beech forests $(300-500 \mathrm{t} / \mathrm{ha})$ and the third - lower mountain Colchis landscapes (250-300 t/ha) [18].

Horizontal structures of the CLSF landscapes have significantly changed since the early period to the present day. In particular, in the study region, until 1980 the phytomass storage reduced from 211.2 million of tons to 104.9 million of tons (i.e. it reduced two times, which is a quite high index). The changes are clearly expressed both according to the individual landscapes and by regions as well. Out of 3 subtypes of the landscapes presented within the Colchis Lowland, the biggest loss of the forest cover and accordingly the phytomass storage is marked in the accumulative hydromorphic landscapes of the Lowland (№ 3), where the phytomass storage has decreased 13 times - from 14.2 million of tons to 1.1 million of tons. Though it is true that the phytomass storage decreased by 1.6 times in the hilly subtropical humid landscapes (Colchis forest) of planes and foothills, but the total loss amounted to much more -74.0 million tons, which exceeds 5 times more than the previous landscape loss.

In the early period of the development of the society the phytomass overall storage within the Colchis Lowland was 211,238 million tones, which is the $18 \%$ of the common storage of the country at that time. This phytomass storage is two times or more reduced. The largest part (almost 1/3) of this storage belonged to Apkhazeti. Phytomass storage was reduced most significantly (3.5 times) in Imereti, and insignificantly - in Guria.

Since the period of post 1980s, on the expense of reduction of the forest cover (especially the powerful forest areas) the phytomass storage was reduced much more, which made 95.4 million tons for the entire Colchis region, and which is 1.3 times less compared to 1980s. The biggest reduction ( 2 times and more) occurred in 3 types of landscapes - in the southern foothill of Nakerala and Samgurali ranges and western foothill of the Likhi range (hilly karst landscape of foothill with shrub hornbeam-oak, hornbeam-oak and polydominant deciduous forests, hilly erosion-denuded landscape of foothill with hornbeam -oak, oak-chestnut forests and evergreen understory and plateau erosion-denuded landscape with hornbeam-oak, oak-beech-chestnut forests and evergreen understory).

\subsection{Main Soil Types and Its Degradation}

A diverse spectrum of soils is presented in the Colchis Lowland and its surrounding foothills [19]. One of the main threats for the Colchis lowland ecosystems are intensive agriculture, deforestation, inappropriate irrigation, intensive and unsystematic grazing, causing soil erosion and degradation.

Bog/Marshy Soils (Silty Bog, Peat Bog) are spread in poorly drained lowland elements of the relief. Characterized by a deep profile, heavy texture, signs of gley, weak neutral $\mathrm{pH}$, high humus content, and heavy texture of the entire profile, high dispersity, uneven distribution of basic oxides, a high 
content of iron forms. The leading elementary soil processes of boggy soils are: gleying, argillization, humification and peat-formation; divided into the following subtypes: mineral-marshy and organic-mineral-marshy soils.

Subtropical Podzolic and Gleysoils (Stagnic Acrisols) occupy weakly elevated marine and river terraces of humid subtropics. They are texturally differentiated with abundant iron concretions in the upper horizons and, sometimes, with a compact ortstein layer at the contact of the lithologically different strata, are acid, have a low to medium content of fulvate humus, a low CEC, a loamy or clayey texture becoming significantly heavier down the profile with signs of gley, and an uneven distribution of oxides. The leading elementary soil processes of lateritic soils are: gleying, allitization, local lessivage, leaching; divided into the following sub-types: surface gleyey, gleyey and gley. Due to topography and sediments containing clay tend to be more resistant to erosion.

The Yellow Soils (Zheltozems - Chromic Alisols) of the foothills in the humid subtropical zone of Georgia are characterized by their deep profiles, yellow color, crumbly structure, high content of fulvate humus, an acid reaction, loamy-clayey texture, and by ferrallitic and siallitic weathering. The leading elementary soil processes of lateritic soils are: ferrallitization, argillization, humification and gleying; divided into the following subtypes: typical, podzolic and gleyed.

The Red /Lateritic Soils (Krasnozems - Rhodic Alisols) of the foothills in the humid subtropics of Western Georgia have deep profiles of red-orange color. They are characterized with a crumb structure, acid reaction, high content of fulvate humus, low and medium CEC, a loamy-clayey, clayey, or heavy clayey texture, high content of $\mathrm{Fe}$ - and Al-oxides and ferrallitic type of weathering. The leading elementary soil processes of lateritic soils are: ferrallitization, argillization and humification; divided into the following subtypes: typical and podzolic.

In the past the area of Yellow and Red soils was represented with Colchis forest - polydominant community (oak, chestnut, beech, alder, buxus, Colchis understory, etc.).

\subsection{Demographic Influence}

The analysis of a modern condition of Georgia's landscapes shows that many structural and functional features are connected with forms of anthropogenic impact. Population, industry, agriculture, transport are the most important forces driving the transformation of landscapes of Georgia [20].

Demographic impact on landscapes can be assessed by indicators such as the number of settlements, number and density of population. According to the data of 1989, over 2,107 million people lived in the study area and the population density was 3,28.3 men per $1 \mathrm{~km} 2$. In 2002, the number of residents reduced by more than 300 thousand and the population density made $1,76.2$ men per $1 \mathrm{~km} 2$.

Major number of settlements $(1,572)$ are located in the subtropical humid landscapes of Colchis Lowland, while the lowest number of them (11) - in the Sub-Mediterranean semi humid, transitive to Colchis landscapes (Bichvinta plain and
Miusera hillside). This can be explained, in the first case, by large area of the landscapes, and in another case - by its small area [3].

The population is very unevenly distributed according to landscapes. The highest number of population is observed within the lowland. There are large areas of urban agglomerations (Kutaisi, Batumi-Kobuleti, Samtredia-Abasha-Senaki) and rural population. Compared to 1989, in 2002 the number of population was reduced in almost every landscape. The only exception is accumulative landscape of the lowland with Imeretian oak forests, in some places with evergreen understory (№ 2), which should be explained by the resettlement of refugees. The highest density of populated is in the moderate transitive to Tbilisi landscapes with the semihumid, forest and shibliak vegetation (№ 13), and on average it is 630 men per $1 \mathrm{~km} 2$.

In 1926-2012 period, an absolute number of the population has increased 1.8 times. The process was marked by the permanent character. In 1989-2012 population initially was declined but after (in 2002-2012) it increased slightly. If we consider existing heavy social and economic conditions, that support negative tendencies of natural movement and migration, it is possible to conclude that in the region there is running a process of depopulation [21].

In Colchis wetlands are important and "interesting" recreational purposes. In case the tourist infrastructure is developed, they may become an important educational and scientific tourism center. In addition, the Colchis wetland areas are located in the center of the recreational objects. There are several important archaeological and historical monuments, famous thermal water outlets and coastal resorts in its close proximity, which increase the recreational importance of the region [22].

\section{Conclusion}

Landscapes of the eastern part and surrounding area of Colchis lowland have experienced the most significant changes and since the early days of human development, the forest area has decreased intensively. Here are marked a high coefficient of demographic influence and transport network density too. Many landscapes which in the past were covered with Colchis forest today are represented with the fragments of forest, wood derivatives and agricultural lands. The most changes took place in the proximity to human settlements. In some places the forest area has been reduced by more than $1 / 3$ or $1 / 2$ from the early stage of human development up to present. But in the western central part of the lowland the forest landscapes are better preserved in their original state.

Based on different sources the following was revealed:

- Some peculiarities of territorial distribution of changes in Georgia's landscapes;

- Some features of historical transformation of CLSF's Landscapes; and

- The study revealed the quality of anthropogenic transformation of the study region's landscapes according to the different indicators (forest area, forest 
rate, phytomass storage, the number of settlements, population density, etc.).

\section{References}

[1] N. Ketskhoveli. "Map of Restored Vegetation of Georgia". Tbilisi, 1959. Scale 1:500,000. (In Georgian).

[2] N.L. Beruchashvili. "Landscape map of Georgia". Tbilisi: TSU, 1979. Scale 1:1,000,000. (In Russian).

[3] D.A. Nikolaishvili Spatial-temporal analyze of Landscapes of Georgia. Tbilisi, 2009. (In Georgian).

[4] N.L. Beruchashvili. "Caucasus: Landscapes, Models, Experiments”. Tbilisi, UNEP-GRID, 1995. (In Russian).

[5] A.G. Tediashvili. "Studying of phytomass as a landscape-geophysical parameter of natural-territorial complexes and its conditions". Tbilisi, 1984. (In Russian).

[6] R. Gagnidze. “Medicinal Vegetation”. Tbilisi: TSU, 2001. (In Georgian).

[7] A. Grossgeim. "Analysis of Flora of Caucasus". Baku, 1936. (In Russian).

[8] A.A. Kolakovski. "Colchis Vegetation". Moscow, 1961. (In Russian).

[9] R. Gagnidze. "Vegetation of Georgia". Tbilisi: TSU, 2001. (In Georgian).

[10] G. Nakhutsrishvili. "Georgia's Basic Biomes. Biological and Landscape Diversity of Georgia". Proceedings of the First National Conference, May 28-29, 1999. Tbilisi, Georgia. Tbilisi, 2001. pp. 43-68.

[11] N.L. Beruchashvili. "Landscape map of Georgia". Types of vertical structure of Natural-territorial complexes (NTCs). Tbilisi, 1983. (In Georgian).
[12] “Colchis Lowland”. Tbilisi: Metsneireba, 1990. (In Russian).

[13] J. Nikuradze, G. Abelishvili, V. Shurgaia, N. Latsabidze. "Meliorative Problems of Colchis Lowland". Tbilisi, 1988.

[14] T. Ramishvili. "Problems of Dehydration of Colchis Lowland". Tbilisi, 1989. (In Georgian).

[15] K. Targamadze, V. Chikhradze. "Forest Resources of Georgia". Tbilisi: Sabchota Sakartvelo, 1976. p.103 (In Georgian).

[16] D. Ukleba. "Anthropogenic Landscapes of Georgia". Tbilisi, 1983. (In Russian).

[17] E. Sokhadze. "Vegetation of Colchis Lowland". In.: Colchis Lowland. Tbilisi: Metsneireba, 1990. pp. 92-96. (In Russian).

[18] D. Nikolaishvili, L.Matchavariani, R. Maisuradze. "Landscape Changes of Georgia: Estimation of an Integrated Parameter". International Journal of Environmental Science and Development. Singapore, 2010. pp. 214-218.

[19] L.G. Matchavariani. "Geographic Paradigms of the Microfabrics of Major Soils of Georgia". Tbilisi, Universal, 2008, 300 p. (In Russian).

[20] D. Nikolaishvili, N.K. Elizbarashvili, G.G. Meladze. Evaluation of Degree of Landscape's Anthropogenic Transformation (Landscapes of Georgia). Proceedings of International Conference GEOMED 2010. Kemer, Antalia, Turkey.

[21] G. Meladze. Dynamics and Natural Movement of the Population of Kolkheti Lowland. International conference "Kolkhety Lowland Water Ecosystems - Protection and Efficient Use". 2013.pp. 134-138. In Georgian.

[22] N. Elizbarashvili. Hydromorphic and Subhidromorphic Landscapes. of Colchis Llowland - Geographical Features and Problems. International conference "Kolkhety Lowland Water Ecosystems - Protection and Efficient Use". 2013.pp. 112-117. In Georgian. 